\title{
O CATECISMO DAS CONSTITUIÇÕES PRIMEIRAS DO ARCEBISPADO DA BAHIA
}

\author{
Ana Palmira Bittencourt Santos Casimiro ${ }^{1}$ \\ Maria Cleidiana Oliveira de Almeida ${ }^{2}$ \\ Camila Nunes Duarte Silveira ${ }^{3}$
}

\section{Resumo}

Este artigo apresenta elementos da análise do catecismo estabelecido pelas Constituições Primeiras do Arcebispado da Bahia, inserido na Colônia Portuguesa da América no início do século XVIII. A partir de uma metodologia bipartida em revisão bibliográfica dos clássicos sobre os conteúdos em pauta e na análise documental, a pesquisa teve por objetivo analisar o modelo de catecismo das Constituições Primeiras (estrutura, funcionamento, forma, conteúdo e finalidade). O estudo das Constituições Primeiras do Arcebispado da Bahia é necessidade fundamental para o conhecimento da atuação catequética da Igreja em terras brasileiras, uma vez que, até o século XIX, elas foram a grande referência canônica e pastoral da Igreja no Brasil, uma colônia escravista e submissa a um Estado absolutista europeu. No decorrer da análise ficou latente que ao criar uma forma de doutrina cristã direcionada aos habitantes da colônia, como uma breve instrução dos mistérios da fé direcionada aos negros escravos, a Igreja conciliou interesses cristãos e políticos, sendo o catecismo expedido pelas Constituições Primeiras, portanto, um documento ideologicamente elaborado.

Palavras-chave: Constituições primeiras. Catecismo. Negros escravos.

\section{THE CATECHISM OF CONSTITUIÇÕES PRIMEIRAS DO ARCEBISPADO DA BAHIA}

\begin{abstract}
This paper presents elements from de analysis of the catechism established by Constituições Primeiras do Arcebispado da Bahia, introduced in the Portuguese colony in the beginning of the 18th century. Based on a split-methodology literature review of the related content and on a documental analysis, the research is aimed at analyzing the model of catechism of Constituições Primeiras (structure, operation, form, contents and purpose). Studies concerning the Constituições Primeiras do Arcebispado da Bahia are of great importance for acquiring knowledge about the catholic church actuation in Brazilian territory, once, they were a great canonical and pastoral reference of the Brazilian church until the $19^{\text {th }}$ century and Brazil was a colony with a slavery system dominated by an European absolutist state. Analysis has made clear that by creating a Christian doctrine destined to the inhabitants of the colony, as a brief instruction about the mysteries of faith destined to the black slaves, the church reconciled Christian and political interests, thus, the catechism issued from Constituições Primeiras is a document ideologically conceived.
\end{abstract}

Keywords: Constituições primeiras. Catechism. Black slaves. 


\section{INTRODUÇÃO}

$\mathrm{Na}$ tentativa de lograr sucesso na catequização, a Igreja fez uso de vários recursos metodológicos: música, teatro, procissões, catecismos, etc. Os catecismos, livros elementares para a organização e sistematização da formação cristã, foram instrumentos largamente utilizados nesse processo e possuem uma longa história, talvez tão longa quanto a própria história da Igreja. Presentes ao longo do cristianismo, os catecismos tornaram-se preciosas memórias de sua tradição, ou seja, uma lembrança de seus ensinamentos, de suas metodologias, de suas linguagens e de suas técnicas de formação cristã, da qual a Igreja nunca se descuidou. É importante destacar que os catecismos eram elaborados com o objetivo de instruir os catecúmenos para o batismo, mas, também, objetivavam iluminar as situações e problemas que se colocavam no caminho da Igreja. Ou, mesmo, resolver problemas do Estado, ao qual a Igreja se associou em vários momentos históricos.

No Brasil, início do século XVIII, foi escrito um novo catecismo instituído pelas Constituições Primeiras do Arcebispado da Bahia. Este modelo de catecismo, objeto de nosso estudo, foi elaborado em reuniões sinodais, que se inspiraram nas disposições do Concílio de Trento, nas Constituições de Évora e de Lisboa. E, como a maioria dos catecismos cristãos de sua época, se pautaram na tradição cristã, nos livros da Sagrada Escritura, nas homilias, nos escritos teológicos dos Primeiros Padres, nas disposições conciliares, no Direito Canônico, nas apologias, nos dogmas, nos cânones, na Patrística e na Escolástica. Uma Escolástica que, em decorrência das transformações do século XVI, havia passado por uma reorganização. Era a Segunda Escolástica, também chamada de Escolástica Espanhola, herdeira da filosofia escolástica clássica. (CASIMIRO, 2002).

Os conteúdos da Escolástica Espanhola, além de discutir e normatizar muitos aspectos do Direito Internacional, decorrente dos descobrimentos modernos, também legislou e criou jurisprudência acerca de novas formas sociais e religiosas surgidas por causa da escravidão em larga escala, questões teológicas ligadas à existência da alma escrava e, principalmente, jurisprudência acerca do direito de escravizar. (CASIMIRO, 2002). Observamos nas notas de rodapé das Constituições muitas citações ou referências aos escolásticos espanhóis Luiz de Molina, Sanchez, Vasquez, Pedro, Domingos Sotto, Navarro, dentre outros. Por esse e outros motivos, concebemos que a análise das Constituições Primeiras do Arcebispado da Bahia é necessidade fundamental para o conhecimento da atuação catequética da Igreja em terras brasileiras, uma vez que, até o século XIX, elas foram a grande referência canônica e pastoral da Igreja no Brasil, uma colônia escravista e submissa a um Estado absolutista europeu.

\section{O CATECISMO DAS CONSTITUIÇÕES PRIMEIRAS DO ARCEBISPADO DA BAHIA: BREVE ANÁLISE}

As Constituições Primeiras do Arcebispado da Bahia tem sua origem no Brasil Colonial. Celebradas em 12 de junho de 1707, as Constituições tiveram sua $1^{\text {a }}$ impressão em Lisboa, no ano de 1719, e em Coimbra, em 1720, com todas as licenças necessárias. Em 1853 foram republicadas, sendo em 2007 reeditadas, por iniciativa do Conselho Editorial do Senado Federal. 


\section{Revista HIIST'TEIDBR On-line}

Artigo

doi: $10.20396 /$ rho.v17i4.8645874

As mencionadas Constituições, nítido reflexo da Igreja Católica no Brasil Colonial, podem ser consideradas, ao lado das Ordenações do Reino, da Mesa de Consciência e Ordens e do Conselho Ultramarino, embriões do ordenamento jurídico e religioso brasileiro, uma vez que, além de regular as ações do clero e dos fiéis, ditaram as regras do "bem viver" para toda a sociedade brasileira por quase dois séculos. Isso foi possível "[...] em uma época em que a religião católica era o principal balizador da mentalidade e da moral das pessoas, que findavam por comportar-se, social e politicamente, segundo os ditames da Igreja". (MAGALHÃES, 2007, p. 8). Assim, por ser a religião católica a religião oficial da colônia, todos deveriam submeter-se às regras que eram impostas por ela, sendo a desobediência passível de punição.

No início do século do XVIII, todas as decisões de caráter religioso dependiam da Coroa lusitana, em virtude do Padroado, que conferia ao rei o lugar de chefe da Igreja. Respaldado legalmente, o Estado Português, na sua expressão absolutista, controlava a Igreja Católica em Portugal e em suas colônias, dentre as quais, a Colônia Brasileira. Por decisão da Coroa, a Igreja Católica no Brasil era regida segundo as Constituições Eclesiásticas de Lisboa e Évora, e de acordo com as disposições do Concílio de Trento. (CASIMIRO, 2002). Essas considerações atestam que, até o início do século XVIII, o Arcebispado da Bahia, como era de se esperar, seguiu as constituições religiosas portuguesas e, ao mesmo tempo, observou os interesses do Estado absolutista português.

[...] o Estado tinha mecanismo de controle sobre todo o organismo colonial, principalmente sobre a própria Igreja. Tanto por conta do Padroado, como por causa das atribuições da Mesa de Consciência e Ordem e do Conselho Ultramarino. Não podemos esquecer, ademais, de que se tratava de um Estado absolutista, regalista, centralizador e monopolizador de quaisquer decisões que viessem de encontro aos seus interesses mercantilistas. (CASIMIRO, 2007, p. 6).

A iniciativa de criar constituições religiosas específicas para o Brasil colonial surgiu no momento em que as constituições portuguesas já não atendiam às necessidades coloniais, ou seja, existiam situações na Colônia que não eram contempladas pela legislação canônica portuguesa. Segundo Casimiro (2002), as diferenças mais marcantes entre a sociedade lusitana e a sociedade brasileira eram aquelas referentes ao tecido social, uma vez que a Colônia Brasileira tinha sua economia pautada na exploração da mão de obra escrava, sendo necessário, portanto, regulá-la religiosa e socialmente. Ainda, segundo a referida autora, a obra, Economia Cristã dos Senhores no Governo dos Escravos, do jesuíta Jorge Benci (1650-1708) foi de grande importância na elaboração das constituições brasileiras, por fornecer, de forma detalhada, as recomendações e diversas atitudes que os senhores e os párocos deveriam adotar, referentes à educação religiosa dos escravos.

Antes de falarmos das Constituições Primeiras do Arcebispado da Bahia, julgamos necessário descrever de forma sucinta o cenário no qual a mesma foi elaborada e, posteriormente inserida. A Colônia Portuguesa na América vivia um período de grandes mudanças: a exploração do pau-brasil, primeira grande riqueza explorada no século XVI, havia sido substituída pela economia açucareira que, em decorrência da concorrência antilhana (segunda metade do século XVII), começava a abrir espaço para a atividade mineradora; politicamente, a colônia se recuperava dos reflexos da União Ibérica (15801640) e, se adaptava às determinações da Dinastia de Bragança, que havia assumido o trono 
Artigo

doi: $10.20396 /$ rho.v17i4.8645874

após a Restauração Portuguesa. Segundo Caio Prado Junior (1987), a política portuguesa adotaria, a partir daquele momento até o fim do período colonial, uma política de arrocho sobre a Colônia do Brasil, que consolidaria sua posição de simples produtora e fornecedora de gêneros úteis ao comércio metropolitano.

A sociedade mantinha uma estratificação social muito rígida: a pequena, mas poderosa, classe dominante formada pelos portugueses e seus descendentes, cujos interesses, fortemente protegidos, opunham-se aos da maioria da população. Por outro lado, uma maioria formada, sobretudo, por escravos que trabalhavam nas mais diversas atividades, em especial, nos engenhos, e na nascente atividade aurífera. Nos engenhos ou nas minas, os escravos eram os sustentáculos da economia colonial, como bem destacou Antonil (1979, p. 89) “Os escravos são as mãos e os pés do senhor do engenho, por que sem eles não é possível fazer, conservar e aumentar fazenda, nem ter engenho corrente".

As Constituições Primeiras do Arcebispado da Bahia, elaboradas nesse cenário, além de formar um compêndio abordando desde questões dogmáticas e da fé até o comportamento das ordens, irmandades, e dos fiéis, procuraram adequar as determinações do Concílio de Trento (1545-1563) às terras brasileiras e às suas peculiaridades.

A obra em estudo, composta por cinco livros, começou a ser elaborada em 1702, em um sínodo Diocesano, que contou com a assessoria de peritos e foi presidido por D. Sebastião Monteiro da Vide. Quinto arcebispo do Brasil, e do Conselho de Sua Majestade, D. Sebastião Monteiro da Vide, foi iniciado na Companhia de Jesus, mas deixou-a para abraçar a vida militar durante a guerra da Restauração. Um pouco mais tarde, ao renunciar à carreira militar, ingressou na Universidade de Coimbra onde estudou Direito Canônico. Após a conclusão de seus estudos tornou-se sacerdote e, logo depois, vigário do Arcebispado de Lisboa, sendo elevado à Dignidade de Metropolitano do Brasil, a cuja Diocese chegou em 22 de maio de 1702. (FERREIRA, 2007).

No curso das duas décadas à frente da Igreja da Bahia, Monteiro da Vide preocupouse em tornar efetivas certas disposições do Concílio de Trento, como demonstram suas visitas pastorais, tanto na cidade de Salvador quanto no Recôncavo e nas paróquias do interior, administrando o sacramento da crisma, privativo dos bispos, a milhares de fiéis. Procurou ainda incentivar os colégios inacianos de Salvador e de Belém e, em Cachoeira, instituiu um centro de formação de sacerdotes. Entretanto, celebrizou-se especialmente, como promotor e organizador do sínodo diocesano, realizado em Salvador, do qual se originaram as Constituições Primeiras. Documento que em substituição às constituições de Lisboa, estendeu-se, nas décadas seguintes, às demais dioceses. (VAINFAS, 2000).

Os livros das Constituições Primeiras foram organizados da seguinte forma: O Livro Primeiro trata da fé católica, da doutrina, da denúncia dos hereges, da adoração, do culto, dos sacramentos; O Livro Segundo trata dos ritos, da missa, da esmola, da guarda dos domingos e dias santos, do jejum, das proibições canônicas, dos dízimos, primícias e oblações; O Livro Terceiro fala sobre as atitudes e o comportamento do clero, das indumentárias clericais, das procissões, do cumprimento dos ofícios divinos, da pregação, do provimento das igrejas, dos livros de registros das paróquias, dos funcionários eclesiásticos, dos mosteiros e igrejas dos conventos; O Livro Quarto fala das imunidades eclesiásticas, da preservação do patrimônio da Igreja, das isenções, privilégios e punições dos clérigos, do poder eclesiástico, dos ornamentos e bens móveis das igrejas, da reverência 
devida e da profanação de lugares sagrados, da imunidade aos acoutados, dos testamentos e legados dos clérigos, dos enterros e das sepulturas, dos ofícios pelos defuntos; o Livro Quinto trata sobre as transgressões (heresias, blasfêmias, feitiçarias, sacrilégio, perjúrio, usura, etc.), das acusações e das respectivas penas (excomunhão, suspensões, prisão etc.).

Não analisaremos este extenso documento normativo na sua totalidade, mas, somente a parte que diz respeito à catequese e ao novo modelo de catecismo concebido e implantado no Brasil. As Constituições Primeiras tratam do ensino da doutrina cristã em dois momentos: no livro primeiro, quando falam da obrigação dos pais, mestres, amos e senhores de ensinar ou fazer ensinar a doutrina cristã aos seus filhos, discípulos, criados e escravos, e no livro terceiro quando se refere à obrigação dos párocos de ensinar a doutrina cristã a seus fregueses. No livro terceiro examinaremos o catecismo apresentado para ensinar a doutrina cristã aos catecúmenos e a breve instrução dos mistérios da fé direcionada à catequização dos escravos do Brasil.

As Constituições Primeiras iniciam a doutrina cristã, como ocorria com quase todos os catecismos, com a profissão de fé em um Deus trino. Segue uma condensada manifestação da fé trinitária e a apresentação do símbolo da fé. Em seguida, apresenta os quatorze artigos da fé, divididos em: sete, que pertencem às três pessoas divinas e outros sete referentes à humanidade de Jesus. Seguem a oração do senhor, a saudação angélica, a salve rainha, os dez mandamentos da lei de Deus e os cinco da Igreja, os sete pecados mortais e as sete virtudes contrárias, os sete sacramentos, o termo da confissão, as oito bem-aventuranças, os sete dons do Espírito Santo, as três virtudes teologais e as quatro cardeais, as três potências da alma e seus três inimigos, os cinco sentidos corporais e os quatro novíssimos do homem, seis pecados contra o Espírito Santo, os pecados que bradam ao céu, as sete obras de misericórdia corporais e as sete espirituais e, finalmente, o completo ato de contrição do Concílio de Trento.

Em 1256, São Tomás de Aquino havia apresentado uma divisão de matéria similar, quando expôs em cinco opúsculos separados o Símbolo, o Padre-Nosso, a Saudação angélica, o Decálogo e os Sacramentos. Vinte e cinco anos depois, o Sínodo de Lambeth transformou os opúsculos tomistas em um conjunto doutrinário, ao qual acrescentou explicações sobre as obras da misericórdia, os sete pecados capitais, e as virtudes que lhes eram contrárias. (MARTINS, 1951).

Não é temerário dizer que desde o século XIII já havia uma ordem tradicional de matéria, que sofreu reduções ou acréscimos a partir das necessidades de cada época. $\mathrm{O}$ Catecismo Romano, por exemplo, foi moldado na teologia de São Tomás e sua matéria foi dividida em De Symbolo Apostolorum, de Sacramentis, de Decalogo, de Oratione praesertim Dominica, que representam a divisão tradicional da doutrina cristã: crer, orar, agir. (MARTINS, 1951).

Diante do exposto, podemos afirmar que o catecismo estabelecido pelas Constituições Primeiras se inspirou em outros catecismos derivados de Trento. Principalmente para estabelecer a sua divisão de matéria que, mesmo sendo mais densa (quantidade de itens) que as propostas por São Tomás e pelo Catecismo Romano, na sua integra não refutava os modelos anteriores. 


\section{Revista HIISTEYIDIR On-line}

O livro terceiro, das Constituições Primeiras, apresenta, também, uma breve forma de catecismo que o pároco deveria reproduzir e distribuir em sua freguesia para que, com ele, os senhores pudessem instruir seus escravos nos mistérios da fé e na Doutrina Cristã. Em vários trechos das Constituições Primeiras é perceptível a preocupação da Igreja em ensinar a doutrina aos negros, uma vez que o conhecimento da doutrina por parte dos adultos era uma condição para a recepção de todos os sacramentos, em particular do batismo. Vale lembrar que, de acordo com a mentalidade da época, a alma do negro não batizado era habitada pelo demônio. (ROCHA, 1993).

Até então, o sistema de catequização direcionado aos escravos negros, havia sido bem diferente dos outros modelos estabelecidos na Colônia. Não era uma catequese realizada como a dos indígenas, em aldeamentos, ou como a dos brancos, em escolas. Ela se realizava nas casas, nas fazendas, nas quais os negros serviam como escravos. Alguns fazendeiros possuíam uma capela e mesmo um capelão com conhecimentos das línguas africanas para facilitar o processo. De forma geral, era uma evangelização apressada e malfeita e os próprios evangelizadores não eram bem preparados. Não que os religiosos coloniais fossem desprovidos de sentimentos cristãos, mas, apresentavam um tipo de cristianismo peculiar àquela cultura.

A legislação das Constituições Primeiras deixa entrever que, na prática da escravidão, os senhores cometeram sérios abusos, sobretudo referentes às obrigações religiosas que deveriam ter para com os seus escravos. Os escravos, muitas vezes, não eram batizados, não recebiam os demais sacramentos, não conheciam as verdades da fé cristã, trabalhavam todos os dias da semana, não guardavam o domingo nem os dias santos. Era preciso, portanto, medidas claras que estabelecessem os deveres cristãos dos senhores, mas, que continuassem mantendo o caráter da legislação escravista.

As Constituições Primeiras, em vários trechos, e citando autores da Segunda Escolástica, insistem que os escravos deveriam ser batizados, poderiam se casar numa celebração cristã e poderiam ser sepultados em terreno sagrado. Além disso, citando Benci (1977), estabeleciam, que os seus proprietários deveriam deixar-lhes tempo necessário à missa dominical, bem como para receber uma instrução religiosa elementar, adaptada à capacidade de compreensão dos mesmos. Por outro lado, o documento sinodal se omitiu totalmente de qualquer discussão sobre os maus tratos aplicados aos escravos, e menos ainda sobre a legitimidade do próprio sistema escravista.

Vejamos o que diz as constituições sobre o matrimônio dos negros escravos ${ }^{4}$ :

Conforme a direito Divino, e humano os escravos, e escravas podem casar com outras pessoas captivas, ou livres, e seus senhores lhe não podem impedir o Matrimônio, nem o uso dellle em tempo, e lugar conveniente, nem por esse respeito os podem tratar peior, nem vender para outros lugares remotos, para onde o outro por ser captivo, ou por ter outro justo impedimento o não possa seguir, e fazendo o contrario peccão mortalmente, e tomão sobre suas conscienciasas culpas de seus escravos, que por este temor se deixão muitas vezes estar, e permanecer em estado de condenação. (VIDE, 2007, p. 125).

E sobre a participação dos escravos nas missas: 
Conformando-nos com o costume geral, mandamos a nossos súbditos, que oução Missa Conventual nos Domingos, e dias Santos de guarda da Igreja Parochial, onde forem fregueses, e a ella fação ir seus filhos, criados, escravos, e todas as mais pessoas, que tiverem a seu cargo, salvo aquelles, que precisamente forem necessários para o serviço, e guarda de suas casas, gados, e fazendas, mas a estes revesarão, para que não fiquem uns sempre sem ouvir a Missa. (VIDE, 2007, p. $145)$.

Era comum no regime de exploração da mão de obra escrava, de forma particular nos engenhos de açúcar, o cultivo e a produção por parte dos próprios escravos de seus alimentos durante os dias santos. Essa prática considerada desumana e cruel foi associada, ao não cumprimento do mandamento de guardar do dia do Senhor. O domingo deveria ser santificado. Os escravos não deveriam trabalhar aos domingos, e deveria ser obrigação do senhor alimentar seus escravos.

A santificação do domingo foi uma memória mantida desde os tempos antigos. Segundo os Atos dos Apóstolos, havia comunidades que se reuniam aos domingos com Paulo para a fração do pão e a liturgia da palavra. (BIBLIA DE JERUSALÉM, 1973, p. 2088). Na primeira Carta aos Coríntios, capítulo 16, versículo 2, Paulo manda que no primeiro dia da semana guardem sua oferta para Jerusalém. (BIBLIA DE JERUSALÉM, 1973, p. 2171). A designação do dia do Senhor encontra-se também em Apocalipse, capítulo 1, versículo 10, e em outros textos apócrifos. Entretanto, foi a ressureição de Jesus no primeiro dia da semana judaica que consagrou o domingo como o dia de um novo começo, conforme vemos em Marcos capítulo 16, versículo 2. (BIBLIA DE JERUSALÉM, 1973, p. 1924).

Para definir os ajustes a serem feitos com relação à catequização dos negros escravos, as Constituições Primeiras fizeram uso da obra do jesuíta Jorge Benci, Economia Cristã dos Senhores no Governo dos Escravos, que apresentava uma normatização das relações e obrigações que os senhores tinham para com os escravos, que seriam: o sustento físico, o pão espiritual (a doutrina cristã), o trabalho e o castigo. Segundo Casimiro (2002), o Sínodo baiano promulgou o conjunto de leis, mas as normas sobre a questão específica da educação dos escravos negros foram, declaradamente, extraídas de Economia Cristã dos Senhores no Governo dos Escravos. Ademais, tanto Jorge Benci quanto o Sínodo muito se apoiaram na Escolástica Espanhola.

No ato de contrição, as Constituições Primeiras mostram que os escravos africanos eram os mais necessitados da doutrina cristã, pois eram de várias nações e possuíam distintas línguas, o que dificultava a comunicação. Para facilitar o ensino da doutrina, e conseguir um melhor aproveitamento, foi pensada uma instrução mais breve e acomodada à "rudeza" dos escravos. O que explica os diversos erros ortográficos, que provavelmente correspondia à maneira como falavam.

Herdeira da racionalidade tridentina, a breve instrução dos mistérios da fé direcionada aos negros escravos, não seguia na íntegra o modelo do Catecismo Romano, uma vez que o modelo adotado pelas Constituições Primeiras era pautado em perguntas e respostas, e o Catecismo Romano era uma exposição temática ou discursiva das verdades cristãs. (MARTINS, 1951) ${ }^{5}$. 


\section{Revista HIIST'TEIDBR On-line}

Artigo

doi: $10.20396 /$ rho.v17i4.8645874

A partir das perguntas e respostas que continha a Breve Instrução, os escravos deveriam ser preparados para fazer a confissão e receber a comunhão. Esse modelo de catecismo rememora o antigo modelo hebraico em que a educação religiosa se ordenava em torno da família e a instrução realizada pelo pai também ocorria por meio de perguntas e respostas. O modelo hebraico foi utilizado por Jesus, que utilizou várias categorias de perguntas para transmitir seus ensinamentos aos discípulos, como podemos observar em várias passagens bíblicas, a exemplo de Lucas, capítulo 14, versículo 3: "É lícito curar no sábado?" (BIBLIA DE JERUSALÉM, 1973, p. 1958); Marcos, capítulo 8, versículo 37: “O que daria o homem em troca da sua alma?" (BIBLIA DE JERUSALÉM, 1973, p. 1910) e Mateus capítulo 22, versículo 18: "Por que me experimentais, hipócritas?" (BIBLIA DE JERUSALÉM, 1973, p. 1880).

Seguindo a pedagogia de Jesus, o modelo pedagógico a que nos referimos foi utilizado em vários contextos da Igreja cristã, inclusive, na elaboração de muitos catecismos. Entretanto, percebemos que no catecismo apresentado pelas Constituições Primeiras os questionamentos eram, na verdade, "pseudoperguntas" uma vez que faziam afirmações em forma de perguntas, e, na realidade, não visavam indagar, almejavam apenas apresentar um ensinamento em forma de pergunta. Cabia ao pároco, através do breve compêndio, apenas transmiti-las, como parte dos ensinamentos cristãos, não induzindo seus interlocutores a uma reflexão. Era uma forma de conseguir facilmente transmitir os ensinamentos cristãos, como bem afirmam as Constituições: "[...] e nesta fórma com bem pouco trabalho seu colherão muito fructo das almas, que estão encommendadas ao seu cuidado". (VIDE, 2007, p. 219).

A breve forma de catecismo funcionou como um recurso persuasivo de retórica que oferecia um pressuposto de "verdade" o qual, por sua vez, impedia o catecúmeno de questionar o que lhe era apresentado. Outra estratégia retórica adotada era a de fazer várias perguntas com a mesma resposta, geralmente curtas; ou mesmo várias respostas que mesmo diferentes, serviam para confirmar uma mesma conjectura enunciada: "P. O teu coração crê tudo que Deos disse? R. Sim. P. O teu coração ama só a Deos? R. Sim. P. Deos há de levarte para o Ceo? R. Sim. P. Queres ir para onde está Deos? R. Sim. P. Queres morrer porque Deos assim quer? R. Sim". (VIDE, 2007, p. 221).

O breve compêndio apresenta o que seria o mínimo para o entendimento da fé, da prática da confíssão e da comunhão, e para um "bem morrer" cristão. Apresentava ao todo cinquenta e duas perguntas divididas, em quatro partes temáticas, referentes à criação, à confissão, à comunhão e ao ato de contrição, junto com as perguntas para os moribundos.

A primeira parte e a mais longa de todas era composta de vinte e nove perguntas e respostas. Aqui transcrevemos um pequeno trecho dela com a ortografia original a qual, segundo as Constituições Primeiras, seria a forma de falar dos escravos no Brasil. Começava assim o breve catecismo:

P.Quem fez este mundo? R. Deos. P. Quem nos fez a nós? R. Deos. P. Deos onde esta? R. No Céu, na Terra e em todo mundo. P. Temos um só Deos ou muitos? R. Temos um só Deos. P. Quantas pessoas? R. Tres. P. Dize os seus nomes? R. Padre, Filho, e Espirito Santo. P. Qual destas Pessoas tomou a nossa carne? R. O Filho. P. Qual destas Pessoas morreo por nós? R. O Filho. P. Como se chama este Filho. R. JESUS Christo. Sua Mãi como se chama? Virgem Maria. (VIDE, 2007, p. 219). 
Diante do exposto, podemos perceber que o tema da criação era o primeiro a ser abordado, seguindo uma tradição catequética antiga e medieval retomada e ampliada pelo IV Concílio Lateranense. O texto seguia apresentando perguntas referentes às pessoas da Trindade, e dava um destaque especial para o Filho e para seu destino depois da morte. Em seguida, apresentava perguntas e respostas sobre a vida após a morte. Nas quinze perguntas e respostas sobre o destino da alma e do corpo após a morte, é possível notar a orientação escatológica, uma vez que a transmissão enfática das noções de céu e inferno fica bastante evidente no texto. Se o catecúmeno aceitasse os ensinamentos cristãos teria um final perfeito, se por outro lado não aceitasse, seu destino seria o inferno ${ }^{6}$ :

P. Quem fez este mundo? R. Deos. P. Quem nos fez a nós? R. Deos. P. Deos onde está? R. No Ceo, na terra, e em todo o mundo. P. Temos um só Deos, ou muitos? R. Temos um só Deos. P. Quantas pessoas? R. Tres. P. Dize os seus nomes R. Padre, Filho, e Espirito Santo. P. Qual destas Pessoas tomou a nossa carne? R. O Filho. P. Qual destas pessoas morreu por nós? R. O Filho, P. Como se chamaeste Filho? R. JESUS Christo. P. Sua Mãi como se chama? R. Virgem Maria. P. Onde morreo este Filho? R. Na Cruz. P. Depois que morreo onde foi? R. Foi lá abaixo da terra buscar as almas boas. P. E depois onde foi? R. Ao Ceo. P. Há de tornar a vir? R. Sim. P. Que há de vir buscar? R. As almas de bom coração. P. E para onde as há de levar? R. Para o Ceo. P. E as almas de máo coração para onde hão de ir? R. Para o inferno. P. Quem está no inferno? R. Está o Diabo. (VIDE, 2007, p. 219).

A orientação escatológica esteve presente desde os primórdios do cristianismo. Em Mateus, capítulo 24, versículo 30, aparece uma versão do discurso escatológico de Jesus: "Então aparecerá no céu o sinal do Filho do homem, e todos os povos da terra se lamentarão e verão o Filho do homem, vindo sobre as nuvens do céu, com poder e grande glória". (BIBLIA DE JERUSALÉM, 1973, p. 1885). O último capítulo da Didaqué (2009) também aborda o tema, ou seja, a hora incerta da segunda vinda de Jesus. Muitos outros nomes importantes da Igreja fizeram suas afirmações sobre os fins dos tempos. O Papa Gregório Magno, por exemplo, despertou uma febre apocalíptica, ao considerar próximo o fim do mundo, um pouco antes, Eusébio de Cesaréia, na História eclesiástica, considerou que a vitória de Constantino era: "a demonstração evidente do estabelecimento atual do reino escatológico de Deus no mundo". Ao abordar o assunto, Le Goff (2012) afirma que a orientação escatológica era bastante comum no mundo judaico-cristão e que ela se formou a partir da Bíblia.

A escatologia judaica continua baseada no Antigo Testamento, enquanto, no cristianismo, os desenvolvimentos feitos pelo Novo Testamento na escatologia veterotestamentária são mais importantes, apesar das variações de interpretação da escatologia neotestamentária. Penso que o último livro do Novo Testamento, o Apocalipse de são João, deva ter um lugar à parte, que pela sua excepcional importância na escatologia cristã, quer pela necessidade de o situar simultaneamente numa literatura judaica e cristã, que ultrapasse em muito o Novo Testamento. (LE GOFF, 2012, p. 326).

Na segunda parte do compêndio, referente à instrução para a confissão, são apresentadas oito perguntas com suas respectivas respostas, que apresentam o objetivo da confissão, os benefícios para quem se confessa e os malefícios para os que escondem os pecados: 


\section{Revista HIIST'TEIDBR On-line}

P. Para que é a Confissão? R. Para lavar a alma do peccado P. Quem faz a confissão esconde peccado? R. Não. P. Quem esconde peccados para onde vai? R. Para o inferno. P. Quem esconde peccados, hade tornar a fazer mais ? R. Não P. Que faz o peccado? R. Mata a alma. P. A alma depois da Confissão torna a viver? R. Sim. P. O teu coração hade tornar a fazer peccado? R. Não. P. Por amor de quem? R. Por amor de Deos. (VIDE, 2007, p. 220).

Na terceira parte da breve instrução, referente aos ensinamentos para a comunhão, são apresentadas nove perguntas sobre o motivo da comunhão e sobre a presença de Jesus na eucaristia:

P. Tu queres Comunhão? R. Sim. P. Para que? R. Para por na alma a nosso Senhor JESUS Christo. P. E quando está nosso Senhor Jesus na Communão? R. Quando o Padre diz as palavras. P. Aonde diz o Padre as palavras? R. Na Missa. P. E quando diz as palavras? R. Quando toma na sua mão a Hostia. P. Antes que o Padre diga as palavras, está já na Hostia nosso Senhor Jesus Christo? R. Não. Está só no pão. P. E quem poza nosso Senhor Jesus Christo na Hostia? Elle mesmo, depois que o Padre disse as palavras. (VIDE, 2007, p. 221).

Na quarta e última parte do compêndio é apresentado um ato de contrição para os escravos e a gente rude: "Meo Deos, meu Senhor: o meu coração só vos quer, e ama: eu tenho feito muitos peccados, e o meu coração doe muito por todos os que fiz. Perdoai-me meu Senhor, não hei de fazer mais peccados: todos boto fora do meu coração, e da minha alma por amor de Deos" (VIDE, 2007, p. 221) e cinco perguntas destinadas aos moribundos que desejassem um morrer cristão: "P.O teu coração crê tudo o que Deos disse? R. Sim. P. O seu coração ama só Deos? R. Sim. P. Deos ha de levarte para o Ceo? R. Sim. P. Queres ir para onde está Deos? R. Sim. P. Queres morrer porque Deos assim quer? R. Sim". (VIDE, 2007, p. 221-222).

Numa perspectiva crítico-construtiva, alguns comentários são dirigidos a este modelo de catecismos perguntas e respostas que, através de técnicas mnemônicas levavam o fiel à memorização, sem investigar o público alvo ao qual se destinava:

[...] redigidos com fins apologéticos, os pequenos catecismos se dirigem mais à razão e à memória, sem levar em conta a vida concreta do destinatário, nem suas questões particulares, nem sua situação pessoa, nem o especifico de sua faixa etária bem como a evolução das faculdades e atitudes pessoais do evangelizador. (MÓRAS, 2004, p. 17-18).

Era comum, os pequenos catecismos terem uma linguagem doutrinal decorativa. Pelas mnemotécnicas, os catecúmenos apreendiam mais facilmente os ensinamentos cristãos. (MORÁS, 2004). O breve compêndio apresentado pelas Constituições Primeiras visava, sobretudo, a conversão dos escravos. Mostra a necessidade de processos mnemônicos para a assimilação dos ensinamentos cristãos, mas, faz uma alegação de que os escravos não estavam aptos a processos mnemônicos extensos, renunciando, portanto, à memorização de orações e formulações doutrinárias, que se acreditavam difíceis de serem lembradas por gente "rude".

Segundo as Constituições Primeiras, o modelo baseado em perguntas e respostas, atenderia melhor aos objetivos da conversão dos negros escravos, uma vez que, trechos mais curtos facilitariam a memorização: "[...] as suas perguntas, e respostas serão as examinadas 
para elles se confessarem, e commungarem Christamente, e com mais facilidade, do que estudando de memoria o Credo, e outras lições, que só servem para os de maior capacidade". (VIDE, 2007, p. 219).

\section{UM PROJETO ESCRAVISTA-CRISTÃO}

Conforme vimos, as Constituições Primeiras estabeleceram uma forma de doutrina simplificada para catequizar os escravos. Entretanto, achamos contraditória essa relação entre escravidão e catequese. Como poderia a Igreja Católica estabelecer um modelo de catequese direcionado aos negros, quando legitimava a escravidão dos filhos da África? Esse tema tão complexo e delicado muito preocupou os estudiosos do assunto, que chegaram a interpretações nem sempre convergentes.

Partindo do pressuposto de que os catecismos eram elaborados de forma pensada e que sua função era principalmente a de convencer os fiéis, buscamos alguns condicionamentos históricos e teológicos que pudessem ter influenciado a Igreja Católica no estabelecimento desse catecismo simplificado direcionado aos escravos.

Contudo, achamos necessário primeiramente deixar claro o posicionamento da Igreja frente à escravidão. Um posicionamento que tem suas origens desde épocas mais remotas, e que, pela memória teológica cristã, foi mudando nos diferentes tempos e lugares. A partir da revisão bibliográfica, podemos afirmar que os fundamentos sobre a escravidão estavam incrustados na mentalidade da Igreja desde a Antiguidade, e atravessou toda a Idade Média até chegar à Idade Moderna. Mas, suas raízes foram fincadas por autores clássicos que, ao longo do tempo, engendraram tal concepção. São Paulo, Santo Agostinho e São Tomás de Aquino foram alguns desses teólogos. Seus posicionamentos frente à questão da escravidão geraram uma memória que foi se ressignificando e se adaptando à compreensão e às conveniências de cada tempo e lugar.

Uma amostra que revela claramente essa adaptação foi o posicionamento distinto que a Igreja Católica adotou com relação à escravização dos indígenas e dos negros africanos, no contexto do Brasil Colonial. Diferentemente da escravização dos indígenas, a escravização dos negros foi de certo modo, invisível aos olhos da Igreja. De alguma forma, a questão da humanidade do escravo negro permaneceu em uma espécie de limbo, zona morta da consciência moral da época, esquecida ou entendida como natural. (WEFFORT, 2012). Podemos inclusive afirmar que a atitude da Igreja Católica frente à escravidão negra foi de conivência, uma vez que várias ordens religiosas possuíam escravos e o tráfico também foi exercido por religiosos. (HOORNAERT, 1983).

A Ordem dos jesuítas, por exemplo, largamente responsável pela educação colonial, apologista do humanismo cristão da Igreja tridentina, herdeira da escolástica de São Tomás, combatente do cativeiro indígena, foi conivente com a escravidão dos negros, tanto que Serafim Leite (2004), em uma análise sobre a postura dos missionários frente à escravidão, afirma que só havia dois caminhos a serem seguidos pelos padres: declararem-se contra a escravidão e serem expulsos do Brasil, ou aceitarem o fato da escravidão e tentarem combater, pelo exercício da caridade, os excessos de violência sofridos pelos negros.

De acordo com Azzi (2008), a principal justificativa apresentada para a escravidão 


\section{Revista HIISTEYIDBR On-line}

negra era a doutrina da guerra justa ${ }^{7}$. Os negros poderiam ser escravizados, desde que capturados num combate envolvendo interesses de promoção da fé no continente africano. Em nível popular, porém, a tese mais difundida para justificar o sistema escravista era a doutrina da maldição divina.

Sob esse prisma, três interpretações diversas, mas convergentes, eram apresentadas para explicar a origem da escravidão negra: a) a primeira versão defendia que a escravidão era consequência do pecado de Adão e da maldição imposta ao homem de trabalhar com o suor de seu rosto; b) a segunda considerava os africanos como descendentes de Caim, e, portanto, traziam na carne a maldição divina. Por ter cometido o primeiro homicídio da humanidade, Deus teria colocado um signo na carne de Caim, para que não fosse morto, mas vivesse continuamente expiando o seu crime. Na tradição popular, a negritude era o sinal imposto por Deus; c) a terceira versão defendia que os africanos eram descendentes de Cam, o filho de Noé, amaldiçoado pelo pai por ter zombado de sua nudez, quando jazia embriagado após ter provado o fruto da videira. (AZZI, 2008).

Salvo raríssimas exceções, não se discutia a imoralidade da escravidão negra dentro da Igreja ${ }^{8}$. O que se discutia, em especial entre os missionários jesuítas, era a forma e os excessos da sua aplicação. Dentre as vozes que se levantaram denunciando os abusos cometidos por senhores e capatazes contra os negros, merece destaque, o já citado jesuíta Jorge Benci, que por meio de sua obra, buscou dar uma feição cristã à escravização colonial, ao estabelecer uma fórmula de aconselhamento para os senhores no trato dos cativos que se baseava no: "[...] panis, disciplinae et opus servo - pão, ensino ou castigo e trabalho, fórmula extraída do Eclesiástico e combinada com Aristóteles”. (VAINFAS, 1986, p. 73).

No decorrer da escravidão colonial, os africanos, arrancados violentamente de seu meio e embarcados em navios infectos para serem escravizados no Brasil, nunca se conformaram. A partir do final do século XVII, as insatisfações eram muitas e cada vez se tornavam iminentes os levantes. O medo que colonos, jesuítas e autoridades régias sentiam de rebeliões negras, se intensificou ainda mais após o levante de Palmares.

\footnotetext{
No contexto das lutas para expulsar os holandeses que se estabeleceram no nordeste brasileiro, se formou em Alagoas um "Estado negro", mais conhecido como Palmares. Um quilombo que conseguiu resistir durante quase cem anos as sucessivas expedições oficiais enviadas para derrotar os quilombolas. (VAINFAS, 1996, p. 64-65).
}

Foi justamente o desejo de evitar novos Palmares que levou a Igreja a desenvolver um projeto escravista-cristão na transição do século XVII para o século XVIII. Segundo o autor, mesmo citando pouco Palmares, que era considerado um assunto tabu dentro da Igreja, o levante teria levado os jesuítas a sérias reflexões acerca da escravidão africana, principalmente a uma solução quanto a conciliar escravidão e catequese dos negros, assunto que já vinha afligindo a Igreja, principalmente os inacianos, havia décadas ${ }^{9}$.

Coincidentemente ou não, nessa época surgiram algumas obras valiosíssimas que podem nos ajudar a entender mais claramente esse novo posicionamento da Igreja frente à escravização dos negros, como exemplo, os Sermões de Vieira, impressos entre 1679 e 1689, o sermonário de Jorge Benci, reunido na Economia Cristã dos Senhores no Governo dos Escravos (1705), a célebre obra de Antonil, Cultura e opulência do Brasil por suas drogas 


\section{Revista HIISTEYIDIR On-line}

Artigo

doi: $10.20396 /$ rho.v17i4.8645874

e minas (1711) e as Constituições Primeiras do Arcebispado da Bahia (1707), obra na qual se encontra o modelo de catequese por nós estudado.

A mensagem que tais obras buscavam introjetar nos colonizadores e colonizados variava conforme o receptor do discurso. Aos escravos recomendava-se o conformismo com a situação de cativo e a esperança de uma vida melhor após a morte. Aos senhores, o tom era quase sempre de ameaça com castigo do Céu e da Terra, caso não cuidassem da salvação espiritual e humana dos negros, negando-lhes, em alguns casos, a possibilidade da catequese e abusando do direito de explorá-los e castigá-los. (VAINFAS, 1996).

Independentemente dos discursos que estas obras tentaram interiorizar em seus receptores, uma coisa é certa, a Igreja havia mudado sua forma de pensar a escravidão africana ${ }^{10}$. Segundo Vainfas (1996), até o século XVI não se percebeu nenhuma preocupação da Igreja com relação à catequese dos africanos, bem como nenhuma indignação contra o apresamento injusto ou contra os castigos exagerados. Para o autor, essa tomada de consciência a partir do Século XVII, está relacionada ao crescimento do tráfico, ao aumento da escravidão no litoral e às constantes rebeliões e fugas de escravos africanos. Foi como se o temor tivesse repentinamente encaminhado os inacianos à possibilidade de desenvolverem um projeto combinando catolicismo tridentino e escravismo, no sentido de amortecer os conflitos.

Vieira, por meio de seus discursos, recomendava que os negros aceitassem o cativeiro, os castigos e as afrontas. Para ele, os negros africanos, a quem chamava de "etíopes", eram os eleitos de Deus e feitos à semelhança de Jesus para salvar a humanidade por meio do sacrifício. Suas ideias eram habilmente encadeadas para demonstrar a similitude entre a condição dos escravos e a de Jesus:

Cristo despido e vós despido: Cristo sem comer e vós famintos; Cristo em tudo maltratado, e vós maltratado em tudo. Os ferros, as prisões, os açoites, as chagas, os nomes afrontosos, de tudo isto se compõe a vossa imitação, que se for acompanhada de paciência, também terá merecimento de martírio. (VIEIRA, 1633, p. 30).

Dessa forma, podemos observar que Vieira pretendia imprimir na mente dos escravos a concepção cristã da escravidão, buscando torná-los conformados com tal situação. Seus discursos visavam levar o negro à aceitação de sua condição e a não rebeldia.

Antonil também se alinhou ao projeto escravista-cristão, mesmo não acentuando a ideia do "pão espiritual" que, segundo ele, sairia muito caro ao projeto jesuítico. Antonil mostrou sua preocupação com os negros ao defender o matrimônio entre os eles, ao se opor às libidinagens desenfreadas, defender os castigos moderados, opor-se às sevícias, e mostrar preocupação com a fuga dos escravos e a formação de quilombos, embora não mencionasse Palmares:

E bem é que saibam que isto lhes há de valer, porque, de outra sorte, fugirão por uma vez para algum mocambo no mato, e se forem apanhados, poderá ser que se matem a si mesmos, antes que o senhor chegue a açoutá-los ou que algum seu parente tome à sua conta a vingança, ou com feitiço, ou com veneno. (ANTONIL, 1979, p. 92). 


\section{Revista HIISTEYIDBR On-line}

Artigo

doi: $10.20396 /$ rho.v17i4.8645874

Antonil escreveu esse sermão no período correspondente ao apogeu e à fase final da guerra de Palmares. Para Vainfas (1996), é impossível ver mera coincidência entre as inquietações jesuíticas com o cativeiro negro e o levante liderado por Zumbi:

Evitar novos Palmares, sem contudo mencioná-lo, eis uma das profundas motivações desse discurso, verdadeiro projeto de cristianizar completamente a escravidão colonial, transformando engenhos em missões, senhores em zelosos missionários, escravos em obedientes filhos de Deus. Utopia conservadora e escravista que admitia os negros no Paraíso, desde que escravos, e os condenava implacavelmente ao Inferno se incorressem no pecado mortal da rebelião. (VAINFAS, 1996, p. 74).

Dentre todos, o receituário mais sistemático dirigido aos senhores para tratar os escravos à moda cristã foi de Jorge Benci que, com seus sermões, empenhou-se em dar uma feição cristã à escravidão colonial. Seus sermões foram agrupados em uma formulação doutrinária para os senhores e os escravos. Com sua obra, Benci (1977), abordou as condições de vida e trabalho dos africanos, além de fornecer regras, normas e modelos para os senhores governarem de forma cristã seus engenhos.

Também as Constituições Primeiras, fortemente influenciadas pelas ideias de Benci, corroboraram com esse modelo escravista-cristão, ao apresentarem uma forma de doutrina simplificada para catequizar os "rudes" escravos:

E porque os escravos do Brasil são os mais necessitados da Doutrina Christã, sendo tantas as nações, e diversidades de linguas, que passão do gentilismo a este Estado, devemos de buscar-lhes todos os meios, para serem instruidosna Fé, ou por quem lhes falle nos seus idiomas, ou no nosso, quando elles já o possão entender. E não há outro meio mais proveitoso, que o de uma instrução accommodada á sua rudeza de entender, e barbaridade de fallar. Portanto serão obrigados os Parochos a mandar fazer copias, (se não bastarem as que mandamos imprimir) de breve fórma do Cathecismo, que vai no titulo 32 para se repartirem por casas dos frequezes, em ordem a ellesinstruirem aos seus escravos nos mysterios da Fé, e Doutrina Chistã, pela fórma da dita instrução, e as suas perguntas, e respostas serão as examinadas, e mais facilmente do que estudado de memoria o Credo; e outras, que aprendem, os que são de mais capacidade. (VIDE, 2007, p. 4).

Igreja e Estado caminharam juntos, e, já que não estavam dispostos a abrir mão dos lucros e benefícios que a escravidão negra lhes trazia, a solução encontrada foi a cristianização dos negros. A evangelização e a catequização foram úteis para a Igreja e para o Estado, já que, com essas práticas, a Igreja poderia manipular a consciência dos negros, fazendo-os aceitarem mais facilmente sua condição de escravos. Na visão dominante, uma vez que aceitassem o Evangelho estariam, ao mesmo tempo, aceitando sua submissão à Coroa. Ambos, Estado Português e Igreja sairiam ganhando. É necessário lembrar que no projeto colonizador e evangelizador, essas duas instituições andaram sempre juntas, uma vez que estavam interligadas pelo Padroado Régio.

Para alcançar seus intuitos, a Igreja usou e abusou da teologia da redistribuição, na qual a dor e o sofrimento deveriam ser aceitos com paciência e obediência por parte dos escravos, na esperança e na certeza de uma retribuição proporcional dada por Deus após a 
morte. Visando uma maior aceitação de seus argumentos, a Igreja chegou a utilizar citações bíblicas e argumentos de teólogos:

[...] permaneça cada um na condição em que se encontrava quando foi chamado. Eras escravo quando foste chamado? Não te preocupes com isto. Ao contrário, ainda que te pudesses tornar livre, procura antes tirar proveito da tua condição de escravo. Pois aquele que era escravo quando chamado pelo Senhor, é um liberto do Senhor. (BIBLIA DE JERUSALÉM, p. 2156).

Acreditamos que nem todos os estudiosos dessa relação contraditória entre catequese e escravidão foram felizes em suas argumentações. Alguns até tentaram mostrar que havia interesses ideológicos, mas, também cristãos, por trás dessa catequização:

A maioria dos estudiosos daquele período concorda em afirmar que, além dos rudimentos da doutrina, o interesse de incorporar os negros à cristandade visava, também, torná-losmais dóceis e mais conformados, na tentativa de adaptá-los à situação de escravidão. Mas isso não quer dizer que a regra fosse geral, pois, havia consciência realmente cristã e que se preocupava deveras com o destino das almas coloniais. (FRAGOSO, 2000, p. 45).

O certo é que, ao imprimir na mente dos escravos a concepção cristã da escravidão, a Igreja Católica cumpria seu papel religioso, sua missão evangelizadora e catequizadora e, ao mesmo tempo, buscava tornar os negros escravos conformados com a situação na qual estavam inseridos. Interesses religiosos e políticos caminharam de mãos dadas.

\section{CONCLUSÃO}

Demonstrar que o modelo de catequese estabelecido pelas Constituições Primeiras do Arcebispado da Bahia, criado e inserido na colônia portuguesa da América, no início do século XVIII, foi herdeiro de uma memória coletiva cristã milenar foi um dos objetivos desse artigo. Uma memória coletiva que, alimentada pela coesão do grupo e mantida pelo sentimento de pertencimento cristão, vem perpassando a longa trajetória da Igreja Católica e orientando, de acordo com as interpretações e interesses de cada contexto, as ações e modelos adotados pela Igreja. Uma vez que a tradição cristã dos primeiros séculos e dos demais períodos da história da Igreja com suas imensas riquezas sempre estiveram presentes, inspirando a teologia da Igreja Católica.

O sínodo responsável pela elaboração do catecismo das Constituições Primeiras fez uso do conjunto das tradições doutrinais, litúrgicas, morais e eclesiais da Igreja. Em sua elaboração, fica visível a utilização dos cabedais do Antigo Testamento e dos Evangelhos; dos ensinamentos dos primeiros Padres, dos conhecimentos da patrística e da escolástica, das disposições conciliares tridentinas, das homilias, dos dogmas e cânones da Igreja, dentre outras tantas contribuições.

A eucaristia, as orações, a missa, dentre outras tantas práticas e ensinamentos cristãos tornaram-se elementos imprescindíveis para a manutenção dessa memória coletiva cristã. Dentre esses elementos, a evangelização e a catequese, incluindo os manuais de instrução e a prática catequética, foram os maiores guardiões dessa memória, porque tinham justamente 
a finalidade de preservá-la. Modelos que, muitas vezes, imbuídos de um discurso ideológico, visavam mais do que evangelizar e catequisar.

A literatura pesquisada aponta, conforme mencionado no texto, que o ajuste entre Igreja e poder temporal se repetiu em muitos momentos da história. As armas mais eficazes desse ajuste provinham justamente dos pensamentos dos seus ideólogos, desdobrados em matérias de teologia moral, direito canônico, escritos espirituais, vidas dos santos e, especialmente, manuais evangelizadores e catequéticos. Enfim, um arsenal ideológico do qual ficava difícil escapar. Documentos elaborados pelos mais capazes pensadores religiosos e intelectuais católicos que serviam como instrumentos de poder e controle dos fiéis, hoje servem como fontes de história e memória da Igreja.

Podemos, portanto, considerar o catecismo das Constituições Primeiras como um documento ideologicamente elaborado, pois foi fruto de escolhas e intenções de quem o elaborou, ou seja, produto da sociedade colonial que o fabricou. Escolhas e intenções por vezes envolvidas em relações de poder. Por outro lado, não podemos negar que as Constituições Primeiras tenham sido precursoras ao estabelecerem um catecismo simplificado para a catequização dos negros escravos, mesmo que sua inserção tenha ocorrido em um momento histórico no qual a Colônia era abalada pelas repercussões do levante de Palmares e que o temor tivesse repentinamente mostrado à Igreja a possibilidade de desenvolver um projeto combinando catequese e escravismo, no sentido de amortecer os conflitos. Ao imprimir na mente dos escravos a concepção cristã da escravidão, a Igreja Católica cumpria seu papel religioso, sua missão evangelizadora e catequizadora e, ao mesmo tempo, buscava tornar os negros escravos conformados com a situação na qual estavam inseridos. Interesses religiosos e políticos caminharam de mãos dadas.

\section{REFERÊNCIAS}

ANTONIL, A. J. Cultura e opulência do Brasil por suas drogas minas (1711), 2. ed. São Paulo: Melhoramentos/INL, 1979.

AZZI, R. A Igreja Católica na formação da sociedade brasileira. Aparecida: Santuário, 2008.

BENCI, J. Economia Cristã dos Senhores no Governo dos Escravos. São Paulo: Grijalbo, 1977.

BÍBLIA DE JERUSALÉM. São Paulo: Paulus, 1973.

CASIMIRO, A. P. B. S. Economia cristã dos senhores no governo dos escravos: uma proposta pedagógica jesuítica no Brasil colonial. 2002. 482 f. Tese (Doutorado em Educação) - Programa de Pós-Graduação em Educação, Universidade Federal da Bahia, Salvador, 2002.

CASIMIRO, A. P. B. S. Igreja, educação e escravidão no brasil colonial. Politéia: História e Sociedade, Vitória da Conquista, v. 7, n. 1, p. 85-102, 2007. Disponível em:

<http://www.uesb.br/politeia/v7/artigo4.pdf .>. Acesso em: 14 abr. 2015. 
DIDAQUÉ. Catecismo dos primeiros cristãos. Petrópolis: Vozes, 2009.

FERREIRA, I. X. Prólogo. In: VIDE, D. S. M. (Org.). Constituições Primeiras do Arcebispado da Bahia. Brasília: Edições do Senado Federal. v. 79, 2007.

FRAGOSO, H. Também sou teu povo, Senhor: Jubileu 2000 - 500 anos evangelizando o Brasil. Paulo Afonso: CNBB, 2000.

HOORNAERT, E. A cristandade durante a primeira época colonial. In: História da Igreja. Petrópolis: Vozes, 1983.

LE GOFF, J. História e memória. 5. ed. Campinas: Ed. da UNICAMP, 2012.

LEITE, S. História da Companhia de Jesus no Brasil, 2004. Tomo II, III, VIII e IX.

MAGALHÃES, A. C. Reafirmando nossa identidade. In: VIDE, S. M. da. Constituições Primeiras do Arcebispado da Bahia. Brasília: Editora do Senado Federal. v. 79, 2007.

MARTINS, L. P. (OFM). Catecismo Romano. Petrópolis: Vozes, 1951.

MORÁS, F. As correntes contemporâneas de catequese. Petrópolis: Vozes, 2004.

PRADO JÚNIOR, C. História econômica do Brasil. São Paulo: Brasiliense, 1987.

ROCHA, M. R. Etíope resgatado, empenhado, sustentado, corrigido, instruído e libertado: discurso sobre a libertação dos escravos no Brasil de 1758. Petrópolis: Vozes, 1993.

VAINFAS, R. Deus contra Palmares: representações senhoriais e ideias jesuíticas. In: REIS, J. J.; GOMES, F. dos S. Liberdade por um fio: história dos quilombos no Brasil. São Paulo: Companhia das Letras, 1996.

VAINFAS, R. Dicionário do Brasil Colonial (1500-1808). Rio de Janeiro: Objetiva, 2000.

VAINFAS, R. Ideologia e escravidão: os letrados e a sociedade escravista no Brasil colonial. Petrópolis: Vozes, 1986.

VIDE, S. M. da. Constituições Primeiras do Arcebispado da Bahia. Brasília: Editora do Senado Federal, 2007.

VIEIRA, A. Sermão XIV. Na Bahia, à irmandade dos pretos de um engenho em dia de são João Evangelista, no ano de 1633. Disponível em: <http:www.cce.ufsc.br/\%7Enupill/ literatura/BT2803039.html>. Acesso em: 11 out. 2017.

WEFFORT, F. C. Espada, cobiça e fé: as origens do Brasil. Rio de Janeiro: Civilização Brasileira, 2012. 


\section{Revista HIISTEYIDIR On-line}

Notas

${ }^{1}$ Doutora em Educação pela UFBA e Pós-Doutora em Educação pela UNICAMP. Professora do Programa de Pós-Graduação em Memória, Linguagem e Sociedade da Universidade Estadual do Sudoeste da Bahia.

(E-mail apcasimiro@hotmail.com).

${ }^{2}$ Mestra em Memória, Linguagem e Sociedade pela Universidade Estadual do Sudoeste da Bahia-UESB. Doutoranda em Memória, Linguagem e Sociedade-UESB. Professora do Instituto Federal da Bahia-IFBA. (Email cleidinha.prof@yahoo.com.br).

${ }^{3}$ Mestra em Memória, Linguagem e Sociedade pela Universidade Estadual do Sudoeste da Bahia-UESB. Doutoranda em Memória, Linguagem e Sociedade- UESB. Bolsista CAPES. (E-mail mila-ped@ hotmail.com).

${ }^{4}$ No caso do matrimônio dos escravos, as Constituições se basearam, especialmente, na obra De Matrimônio, do espanhol Tomás Sanchez (1610).

${ }^{5}$ Apenas uma edição anônima do Catecismo Romano publicada na Antuérpia em 1574 dividia o texto original em perguntas e respostas (MARTINS, 1951).

${ }^{6}$ Vale lembrar que a memória dessas ameaças escatológicas estavam sempre presentes nos principais sermões publicados pelos religiosos da época, mormente Vieira, Benci, Antonil, Manuel Bernardes, Manoel Ribeiro Rocha, dentre outros (CASIMIRO, 2002).

${ }^{7}$ Essa justificativa da guerra justa tem sua defesa principalmente na obra Justitia e Jure do jesuíta Luiz de Molina (1535-1600) (LEITE, 2004).

${ }^{8}$ Alguns padres se levantaram conta a escravidão dos negros e foram punidos por adotarem tal atitude, podemos citar alguns exemplos: Padre Gonçalo Leite (1546-1603), Padre Miguel Garcia (1550-1614), Padre Gabriel Malagrida (1689-1760).

${ }^{9}$ Os jesuítas falaram pouco sobre Palmares, mas falaram muito sobre a escravidão.

${ }^{10}$ Não pretendemos aqui estabelecer nenhum juízo de valor sobre as obras citadas. Desejamos apenas mostrar que por trás de suas elaborações estavam intrínsecos os interesses ideológicos da época, ou seja, as tendências teológicas discutidas naquele momento.

Submetido em: 30/04/2016

Aprovado em: 20/09/2017 